\title{
KEPUASAN MAHASISWA STRATA 1 DI KABUPATEN MAJALENGKA DITINJAU DARI PERSPEKTIF KUALITAS PELAYANAN DOSEN DALAM PEMBELAJARAN DARING Oleh:
}

Ahmad Kamaludin - STIE STMY Majalengka Email: ahmad.akaok67@gmail.com

\section{Article Info}

Article History :

Received 30 August 2021

Accepted 16 Sept - 2021

Available Online 25

Sept - 2021

\section{Keyword :}

\section{Abstract}

This study aims to determine or analyze the influence of the quality of lecturer service on the satisfaction of undergraduate students in universities in the Majalengka Regency area. The method used is descriptive quantitative with an explanatory survey approach. The survey was conducted by distributing questionnaires made through google form and obtained 250 feedback responses for analysis. Data were analyzed through classical assumption test, hypothesis testing, simple linear regression test, and coefficient of determination using SPSS application. The service quality of lecturers has a positive and significant effect on student satisfaction. The independent variable cannot provide a comprehensive explanation in answering the problem of the level of satisfaction of undergraduate students in universities in the Majalengka Regency area. The research findings can be used as information for universities in the Majalengka Regency area to increase the level of student satisfaction and as empirical evidence that may be useful for further research.

Student Satisfaction,

Service Quality,

Universities, Majalengka

Regency.

\section{PENDAHULUAN}

World Health Organization (WHO) mengumumkan pada tanggal 11 Maret 2020 bahwa COVID-19 dinyatakan sebagai pandemi. Sampai saat ini ada 215 negara yang terjangkit virus corona, dengan laporan terinfeksi sebanyak 12.768.307 kasus yang terjangkit (WHO, 2020). Indonesia adalah salah satu negara yang terjangkit COVID-19. Pada Maret 2020, Indonesia merasakan dampak dari pandemi COVID-19 yang berdampak pada terbatasnya mobilitas masyarakat, tak terkecuali kegiatan belajar mengajar disetiap tingkatan pendidikan.

Pemerintah mengeluarkan kebijakan pelaksanaan pembelajaran daring untuk memastikan pembelajaran dimasa pandemic berjalan baik dengan mengutamakan kesehatan dan keselamatan civitas akademik. Ciri dari pembelajaran online atau daring adalah integrasi teknologi dan inovasi yang ada didalamnya (Banggur et al., 2018). COVID-19 membuat suatu uji coba terhadap pelaksanaan pendidikan secara daring yang dilakukan secara massal 
(Sun et al., 2020). Pemerintah melalui keputusan bersama 4 menteri mengeluarkan keputusan bahwa proses pembelajaran khususnya di jenjang pendidikan tinggi pada semester gasal tahun akademik 2020/2021 di semua zona wajib diselenggarakan secara daring. Perubahan dari pelaksanaan pembelajaran dalam kelas hingga pelaksanaan pembelajaran dalam jaringan ini, yang berperan sebagai aktor terpenting ialah guru dan pendidik, karena mereka adalah pengendali dalam proses pembelajaran (Bao, 2020; Braisilaia \& Kvavadze, 2020)

Menteri Pendidikan dan Kebudayaan mengeluarkan kebijakan jika pembelajaran di Perguruan Tinggi dilakukan secara daring (Kasih, 2020). Kebijakan tersebut harus dipatuhi oleh semua Perguruan Tinggi sebagai bentuk patuh pada penerapan Pembatasan Sosial Berskala Besar (PSBB), termasuk yang ada di Kabupaten Majalengka. Pelaksanaan PSBB didasarkan pada payung hukum berupa Peraturan Pemerintah nomor 21 Tahun 2020 pembatasan sosial berskala besar dalam rangka percepatan penanganan COVID19. Selain itu Peraturan Gubernur Nomor 36 Tahun 2020 tentang Pedoman PSBB dalam Rangka Percepatan Penanggulangan COVID-19 di Wilayah Provinsi Jawa Barat. Seiring dengan peraturan gubernur pemerintah kabupaten Majalengka juga mengeluarkan peraturan Bupati Majalengka Nomor 54 Tahun 2020.

Kebijakan pembelajaran daring mendapat berbagai macam respons dari publik. Meskipun tidak ideal, pembelajaran daring dianggap sebagai satu-satunya kebijakan yang memungkinkan proses pembelajaran tetap bisa dilakukan di tengah pandemi COVID-19. Kondisi geografi di Majalengka sangat tidak memungkinkan untuk peneran pembelajaran dengan daring dengan waktu berkepanjangan. Peraturan Bupati yang memberikan batasan melalui PSBB dipandang di Kabupaten Majalengka membuat proses pembelajaran sangat terhambat.
Terhambatnya proses pembelajaran di Perguruan Tinggi berdampak pada kepuasan mahasiswa terhadap aspekaspek yang menjadi haknya, seperti pelayanan akademik yang diberikan oleh dosen.

Kepuasan merupakan perasaan senang atau kecewa seseorang yang muncul setelah membandingkan kinerja (hasil) produk yang dirasakan dengan kinerja (atau hasil) yang diharapkan (Kotler dan Keller, 2016). Penilaian tingkat kepuasan mahasiswa yang merupakan salah satu aspek penilaian terhadap kualitas pelayanan pendidikan memiliki arti penting bagi kelangsungan sistem pendidikan. Hasil penilaian tingkat kepuasan mahasiswa dapat digunakan untuk mengarahkan sistem pendidikan yang lebih baik (Herawati dan Setialeksana, 2016). Beberapa hasil penelitian sebelumnya menyatakan pengaruh dari kualitas layanan terhadap kepuasan mahasiswa, seperti Uluputty dan Junaidin (2019), menemukan pengaruh negatif, dan penelitian lain menyatakan pengaruh positif (Hanafi et al., 2020; Marzuki et al., 2019; Saifuddin dan Sunarsih, 2016; Firdaus et al., 2021).

\section{KAJIAN PUSTAKA, KERANGKA PEMIKIRAN DAN HIPOTESIS Kualitas Pelayanan Dosen}

Kualitas pelayanan adalah upaya pemenuhan dan keinginan konsumen serta ketetapan penyampaiannya dalam mengimbangi harapan konsumen (Tjiptono, 2014) Keberhasilan organisasi dalam memberikan pelayanan yang berkualitas dapat ditentukan dengan pendapat service quality (servqual) yang telah dikembangkan oleh organisasi (Lupiyoadi dan Hamdani, 2010). Servqual yang dimaksud merupakan seberapa jauh perbedaan antara harapan dan kenyataan para pelanggan atas layanan yang mereka terima.

Servqual dapat diketahui dengan cara membandingkan dengan persepsi pelanggan atas layanan yang benar-benar mereka terima dengan pelayanan sesungguhnya yang mereka harapkan. Kualitas pelayanan menjadi hal utama 
yang diperhatikan serius oleh organisasi yang melibatkan seluruh sumber daya yang dimiliki. Kualitas layanan atau servqual dapat diukur melalui 5 dimensi (Tjiptono, 2014), yaitu:

1. Bukti fisik (tangible), meliputi penampilan fasilitas fisik, perlengkapan, pegawai, dan sarana komunikasi.

2. Kehandalan (reability) yaitu kemampuan memberikan pelayanan yang dijanjikan dengan segera, akurat, dan memuaskan.

3. Ketanggapan (responsiveness) dalam memberikan layanan.

4. Jaminan dan kepastian (assurance) mencakup pengetahuan dan kompetensi dosen.

5. Empati (empathy), meliputi kemudahan dalam menjalin relasi, komonikasi yang baik, dan pemahaman atas kebutuhan individual mahasiswa.

\section{Kepuasan Mahasiswa}

Mahasiswa merupakan pelanggan dari Perguruan Tinggi karena mahasiswa mempunyai hak untuk dilayani oleh institusi. Kepuasan merupakan penilaian antara kesesuaian harapan terhadap kinerja produk atau jasa yang dibeli (Tjiptono, 2014). Kepuasan dapat diukur dengan 2 dimensi (Tjiptono, 2014), yaitu:

\section{Kualitas Pelayanan}

1. Kesesuaian harapan, Tingkat kesesuaian antara layanan kampus yang diharapkan dengan dirasakan oleh mahasiswa, termasuk layanan pendukung dan fasilitas yang diperoleh.

2. Bersedia merekomendasikan, kesediaan mahasiswa merekomendasikan kampus kepada teman atau keluarga.

\section{Kerangka Pemikiran dan Hipotesis}

Konsep kepuasan mahasiswa terkait erat dengan kesesuaian antara harapan dan kenyataan dari kualitas pelayanan pendidikan yang di dapat dari kampus tersebut (Sutartiah, 2017). Service quality (servqual) merupakan suatu konsep secara tepat mewakili inti dari kinerja suatu jasa, yaitu perbandingan terhadap keterandalan (excelince) dalam service encounter yang dilakukan oleh konsumen (Parasuraman et al. dalam Muhtifah et al., 2019). Beberapa hasil penelitian sebelumnya menyatakan pengaruh dari kualitas layanan terhadap kepuasan mahasiswa, seperti Uluputty dan Junaidin (2019), menemukan pengaruh negatif, dan penelitian lain menyatakan pengaruh positif (Hanafi et al., 2020; Marzuki et al., 2019; Saifuddin dan Sunarsih, 2016; Firdaus et al., 2021). Berdasarkan hal tersebut, maka model penelitian ini ditunjukkan oleh Gambar 1 dibawah ini.

Kepuasan Mahasiswa

\section{Gambar 1. Model Penelitian}

Berdasarkan Gambar 1 diatas, maka hipotesis dalam penelitian ini adalah kualitas pelayanan berpengaruh terhadap kepuasan mahasiswa.

\section{METODE PENELITIAN}

Metode yang digunakan adalah metode deskriptif kuantitatif dengan desain penelitian eksplanatori survey yang bertujuan untuk menjelaskan hubungan antara variabel penelitian. Metode pengumpulan data penelitian ini dengan cara survey sebagai data primer menggunakan kuesioner berisi pernyataan tertulis yang digunakan untuk memperoleh informasi dari responden. Selain itu, digunakan pula data sekunder berupa data yang diperoleh dari buku maupun jurnal ilmiah yang berkaitan dengan kualitas layanan dan kepuasan mahasiswa. Penelitian ini terdiri dari variabel bebas $(\mathrm{X})$ dan variabel terikat (Y). Variabel bebas dalam penelitian ini adalah kualitas layanan (X), sedangkan yang menjadi variabel terikat $(\mathrm{Y})$ adalah kepuasan mahasiswa. Penjabaran operasionalisasi dari variabel-variabel yang diteliti dapat dilihat pada Tabel 1 di bawah ini. 
Tabel 1

Operasionalisasi Variabel

\begin{tabular}{|c|c|c|c|}
\hline Variabel & Dimensi & Indikator & Skala \\
\hline $\begin{array}{c}\text { Kualitas Layanan } \\
\text { Kualitas pelayanan adalah } \\
\text { upaya pemenuhan dan } \\
\text { keinginan konsumen serta } \\
\text { ketetapan penyampaiannya } \\
\text { dalam mengimbangi harapan } \\
\text { konsumen. } \\
\text { (Tjiptono, 2014) }\end{array}$ & $\begin{array}{ll}\text { 1. } & \text { Tangible } \\
\text { 2. } & \text { Reliability } \\
\text { 3. } & \text { Responsiveness } \\
\text { 4. } & \text { Assurance } \\
\text { 5. } & \text { Empathy }\end{array}$ & $\begin{array}{l}\text { a. Fasilitas Selama Pembelajaran } \\
\text { Daring. } \\
\text { b. Layanan Dosen Selama } \\
\text { Pembelajaran Daring. } \\
\text { c. Layanan Tenaga Pendidik Selama } \\
\text { Pembelajaran Daring. } \\
\text { d. Ketanggapan representative } \\
\text { kampus Selama Pembelajaran } \\
\text { Daring. } \\
\text { e. Transfer ilmu Selama Pembelajaran } \\
\text { faring. } \\
\text { f. Kemampuan dosen Selama } \\
\text { g. Pembelajaran Daring. } \\
\text { Pemenuhan kebutuhan mahasiswa }\end{array}$ & Interval \\
\hline Kepuasan Mahasiswa & $\begin{array}{l}\text { 1. Kesesuaian Harapan } \\
\text { 2. Kesediaan } \\
\text { Memberikan } \\
\text { Rekomendasi }\end{array}$ & $\begin{array}{l}\text { a. Fasilitas Kampus Sesuai Harapan } \\
\text { Mahasiswa. } \\
\text { b. Layanan Kampus Sesuai Harapan } \\
\text { Mahasiswa. } \\
\text { c. Mahasiswa Memberikan } \\
\text { Rekomendasi Kepada Teman. } \\
\text { d. Mahasiswa Memberikan } \\
\text { Rekomendasi Kepada Anggota } \\
\text { Keluarga. }\end{array}$ & Interval \\
\hline
\end{tabular}

Populasi dalam penelitian ini adalah Mahasiswa Strata 1 di Perguruan Tinggi di Wilayah Majalengka. Kuesioner dibuat menggunakan google form dan disebar melalui tautan, kemudian didapat tanggapan sebanyak 250 responden. Model analisis yang digunakan adalah analisis regresi linear sederhana dan nilai koefisien determinasi. Penggunaan analisis ini bertujuan untuk mengetahui pengaruh antara variabel bebas terhadap variabel terikat, yaitu kualitas layanan dosen (X1) terhadap kepuasan mahasiswa (Y) dengan persamaan umum sebagai

\section{HASIL DAN PEMBAHASAN}

\section{Uji Hipotesis}

berikut: : $\mathrm{Y}=\alpha+\mathrm{b} 1 \mathrm{X} 1+\mathrm{e}$. Metode pengujian Hipotesis menggunakan Uji t untuk menunjukan pengaruh suatu variabel bebas terhadap variabel terikat secara parsial.

Instrumen yang dipakai perlu diuji terlebih dahulu validitas dan reliabilitasnya untuk mengetahui apakah kuesioner benar dan layak untuk dipakai dalam menguji hubungan dan pengaruh antara variabel penelitian. Instrument dikatakan valid jika nilai "corrected item-total correlation" diatas 0,40. Instrument dikatakan reliabel jika nilai Cronbach's alpha $>0.70$.

Tabel 5

Hasil Uji Hipotesis

\begin{tabular}{|c|c|c|c|c|c|}
\hline \multirow[b]{2}{*}{ Model } & \multicolumn{2}{|c|}{$\begin{array}{c}\text { Unstandardized } \\
\text { Coefficients }\end{array}$} & \multirow{2}{*}{$\begin{array}{c}\begin{array}{c}\text { Standardized } \\
\text { Coefficients }\end{array} \\
\text { Beta }\end{array}$} & \multirow[b]{2}{*}{$\mathrm{t}$} & \multirow[b]{2}{*}{ Sig. } \\
\hline & $\mathrm{B}$ & Std. Error & & & \\
\hline $\begin{array}{ll}1 & \text { (Constant) } \\
& \text { KUALITAS } \\
& \text { PELAYANAN } \\
& \text { DOSEN }\end{array}$ & .816 & .874 & .759 & $\begin{array}{r}.933 \\
18.332\end{array}$ & .352 \\
\hline
\end{tabular}


Berdasarkan Tabel 5, diperoleh kesimpulan bahwa nilai probability (signifikansi) pengaruh variabel kualitas layanan dosen terhadap kepuasan mahasiswa lebih kecil dari 0.05 , yaitu 0,00 , maka hipotesis diterima. Jika dilihat dari nilai $\mathrm{t}$ hitungnya 18.332 juga ternyata lebih kecil dari $\mathrm{t}$ tabel yaitu 1,969 sehingga kesimpulannya sama maka hipotesis diterima, artinya kualitas pelayanan dosen berpengaruh terhadap kepuasan mahasiswa. Peningkatan kualitas pelayanan dosen akan meningkatkan kepuasan mahasiswa.

\section{Uji Korelasi dan Koefisien Determinasi}

Analisis regresi digunakan untuk menganalisis hubungan antar variabel yang menjadi ramalan dan variabel yang dipercaya secara statistik berhubungan dengan variabel ramalan. Berdasarkan tabel 5 diatas, diperoleh persamaan regresi $\mathrm{Y}=0,816+0,441 \mathrm{X} 1+\mathrm{e}$. Tanda $(+)$ menunjukkan hubungan positif antara variabel berjalan dua arah arah yang artinya semakin tinggi variabel kualitas pelayanan dosen, maka semakin tinggi kepuasan mahasiswa.

Tabel 6

Model Summary

\begin{tabular}{|l|r|r|r|r|}
\hline Model & $\mathrm{R}$ & R Square & $\begin{array}{c}\text { Adjusted R } \\
\text { Square }\end{array}$ & $\begin{array}{c}\text { Std. Error of } \\
\text { the Estimate }\end{array}$ \\
\hline 1 & $.759^{\mathrm{a}}$ & .575 & .574 & 1.838 \\
\hline
\end{tabular}

a. Predictors: (Constant), KUALITAS PELAYANAN DOSEN

b. Dependent Variable: KEPUASAN MAHASISWA

Berdasarkan informasi pada tabel 6, diperoleh informasi bahwa korelasi antar variabel sebesar $75,9 \%$ dan tergolong sangat kuat. Nilai koefisien determinasi (adjusted $R$ square) sebesar 0,575 menunjukkan bahwa variabel independen memberikan pengaruh sebesar $57,5 \%$ terhadap variabel dependent, sedangkan sisanya sebesar 42,5\% kepuasan mahasiswa strata 1 di Kabupaten Majalengka dipengaruhi oleh variabel lain yang tidak diteliti dalam penelitian ini. Hasil penelitian sejalan dengan beberapa hasil penelitian sebelumnya yang menyatakan pengaruh positif dan signifikan dari kualitas layanan dosen terhadap kepuasan mahasiswa (Hanafi et al., 2020; Marzuki et al., 2019; Saifuddin dan Sunarsih, 2016; Firdaus et al., 2021) serta bertolak belakang dengan hasil penelitian Uluputty dan Junaidin (2019).

Sebagai suatu lembaga, Perguruan Tinggi dikelola dengan berpedoman pada kepentingan civitas akademika yang terdiri dari mahasiswa, tenaga pengajar, dan karyawan. Suatu Perguruan Tinggi seyogyanya dilengkapi dengan berbagai macam fasilitas guna mendukung keberhasilan dalam suatu kualitas pelayanan. Salah satu yang mendukung keberhasilan suatu Perguruan Tinggi adalah kualitas pelayanan dosen dalam rangka melaksanakan Tri Dharma melalui penyediaan, pengorganisasian dan memberikan pelayanan kepada mahasiswa.

Pasolong (2008) menjelaskan jika salah satu ukuran keberhasilan menyajikan pelayanan yang berkualitas sangat tergantung pada kepuasan pelanggan yang dilayani (dalam hal ini mahasiswa). Kualitas pelayanan berpengaruh signifikan terhadap kepuasan. Hal ini menunjukkan bahwa penilaian mahasiswa terhadap tingkat kepuasan mereka didasarkan pada selisih atau perbedaan antara ekspektasi terhadap layanan dengan layanan actual yang didapatkan. Kepuasan mahasiswa dapat diketahui melalui pengukuran perbedaan antara apa yang diharapkan mahasiswa dengan apa yang diterima oleh mereka dari penyedia layanan (dalam hal ini kampus melalui kualitas layanan dosen). 
Tjiptono (2014) menyatakan bahwa kualitas layanan mempunyai hubungan yang erat dengan kepuasan. Kualitas memberikan suatu dorongan kepada mahasiswa untuk menjalin ikatan hubungan yang kuat dengan kampus. Dalam jangka panjang, ikatan yang kuat seperti ini memungkinkan pihak kampus untuk memahami dengan seksama harapan mahasiswa serta kebutuhan mereka.

\section{KESIMPULAN DAN SARAN}

Perguruan Tinggi sebagai institusi mempunyai kewajiban untuk memberikan pelayanan terbaik kepada mahasiswa. Pelayanan terbaik yang dimaksud meliputi fasilitas dan pelayanan tenaga pengajar (dosen). Oleh karena itu, perguruan tinggi harus dapat menjamin mahasiswa mendapatkan layanan terbaik dengan menjamin dosen mampu memberikan ilmu dan layanan pembelajaran lainnya secara optimal. Keadaan pandemic yang memaksa pembelajaran dilakukan secara daring tidak bisa dijadikan alasan menurunnya kualitas layanan yang diberikan pihak kampus melalui dosen. Kualitas layanan dosen yang baik akan meningkatkan kepuasan mahasiswa.

\section{REFERENSI}

Banggur, M. D. V., Situmorang, R., \& Rusmono, R. (2018). Pengembangan Pembelajaran Berbasis Blended Learning Pada Mata Pelajaran Etimologi Multimedia. JTP - Jurnal Teknologi Pendidikan, 20(2), 152-165.

https://doi.org/10.21009/jtp.v20i 2.8629

Bao, W. (2020). COVID-19 and online teaching in higher education: A case study of Peking University. Pedagogical Research, 5(4), 113-115.

https://doi.org/https://doi.org/10/ 1002/he2.191

Braisilaia, G., \& Kvavadze, D. (2020). Transition to online education in schools during a pandemic in Georgia. Pedagogical Research, 5(4),

1-9. https://doi.org/https://doi.org/10. 29333/pr/7937

Firdaus, Syarif, Darmo H. Suwiryo, Fenty Sukmawaty. (2021). Pengaruh Kualitas Pelayanan Akademik dan Kompetensi Dosen terhadap Kepuasan Mahasiswa. JURNAL ILMIAH MUQODDIMAH Vol. 5 No. 2 Hal: 320-328

Hanafi, R., Mansur, M., \& Hufron, M. (2020). Pengaruh Kualitas Pelayanan Dosen Dan Fasilitas Perkuliahan Terhadap Kepuasan Mahasiswa Fakultas Ekonomi Dan Bisnis Universitas Islam Malang. e - Jurnal Riset Manajemen PRODI MANAJEMEN Fakultas Ekonomi Unisma.

Herawati, L., dan Setialeksana, D., 2016. Kepuasan Mahasiswa Berdasarkan Kinerja Dosen dalam Proses Perkuliahan di FKIP Jurusan Matematika Universitas Siliwangi. Jurnal Siliwangi. 2 (2) : 131 - 136.

Kasih, Ayunda Pininta (2020). Mendikbud: Perguruan Tinggi di Semua ZonaDilarang Kuliah Tatap Muka. Diakses Pada 5 September 2021 melalui https://www.kompas.com/edu/re ad/2020/06/16/103917571/mend ikbud-perguruan-tinggi-disemua-zona-dilarang-kuliahtatap-muka

Kotler, Phillip dan Kevin Lane Keller (2016), Marketing Management, Edisi 15, England: Pearson Education Limited.

Lupiyoadi, \& Hamdani. (2010). Manajemen Pemasaran Jasa. Jakarta: Salemba Empat.

Marzuki, M. F., Nurwati, \& Rommy, N. (2019). Pengaruh Kualitas Layanan Dan Kompetensi Dosen Terhadap Kepuasan Mahasiswa. JUMBO ( Jurnal Manajemen , Bisnis , Dan Organisasi ) Univerisias Halu Oleo, 3(3), 8597. 
Muhtifah, L., E. Hendry. AR., M. Rahmatullah, Suhardiman. (2019). Survei Kepuasan Mahasiswa Dan Dosen Terhadap Kualitas Pelayanan Pendidikan Dengan Pendekatan Servqual. Jurnal Islamic Education Manajemen 4 (1) (2019) 105-118 https://doi.org/10.15575/isema.v $3 \mathrm{i} 2.5296$

Pasolong, 2008 Faktor Kualitas Layanan, Andi, Yogyakarta

Saifuddin, \& Sunarsih. (2016). Pengaruh Kualitas Pelayanan terhadap Kepuasan Mahasiswa UIN Sunan Kalijaga Yogyakarta 1. 8(2), 177-216.

Sun, L., Tang, Y., \& Zuo, W. (2020). Corona virus pushes education online. Nature Material, 19, 687. https://doi.org/10.1038/s41563$\underline{020-0678-8}$
Sutartiah, F. (2017). Evaluasi Kepuasan Mahasiswa Terhadap Kualitas Pelayanan Pendidikan Lembaga Pendidikan Tinggi ABC di Cikarang. Jurnal Formatif Vol. 7, No. $\quad 1$ 55-65. http://dx.doi.org/10.30998/forma tif.v7i1.1372

Tjiptono, Fandy. 2014, Pemasaran Jasa : Prinsip, Penerapan, dan Penelitian, Andi Offset, Yogyakarta.

Uluputty, N.F. \& Junaidin. (2019). Pengaruh Kualitas Pelayanan, Budaya Akademik Dan Kinerja Dosen Terhadap Kepuasan Mahasiswa. Jurnal Ekonomi dan Manajemen Vol. 1 No. 2 Hal:111

WHO. (2020). Corona virus disease (COVID-19) pandemic. World Helath Organization. 